\title{
Pedal Powered Water Pump Application To Support Irrigation Activities In Carat Village, Gempol District, Pasuruan Regency, East Java Province
}

\author{
Author \\ Hatta, Mochammad, Tjahjani, IK., Wicaksono, AS.
}

\author{
Correspondence \\ Universitas 45 Surabaya, Universitas 45 Surabaya, Universitas Muhammadiyah Gresik. \\ hattahattahatta@gmail.com, idakusnawati43@gmail.com, awangwicaksono.psi@umg.ac.id
}

\begin{abstract}
:
In this PKM program, our partner is a fruit farmer in Carat Village, which is the name of a village in Gempol District, Pasuruan Regency, East Java Province. This village actually has the opportunity to develop in the plantation sector with its main plants cucumber, cantaloupe, cucumber mas, and roses. However, it is constrained by the condition of very barren rice fields and plantations covering an area of 60 hectares, due to the lack of support for the local irrigation system currently being implemented.

Based on interviews and observations in the field, there are 2 main focuses of the problems currently faced by partners, namely: 1) The production sector is caused by the large amount of energy that must be spent to draw water from the well with the distance of the water source to the plantation using simple equipment and 2). Field of management due to the under-optimal distribution of crop yields and monitoring functions of yields in each period.

Some of the things planned by the PKM team are innovating bicycles which are named pedal power as plantation irrigation equipment and solutions in the field of production, as well as providing training and mentoring in financial reporting as a solution in the field of management. The purpose of this activity is to realize a system improvement, increase crop production, and create effective, efficient and competitive management.

This activity was realized with an approach in the form of making a sustainable cooperation program until the end of PKM, creating a family atmosphere between the two and understanding that the problems experienced were a shared problem so that they could be solved together according to the level of responsibility to achieve the expected benefits, namely increased yields, production and productivity and competitiveness, independence and welfare of the community.
\end{abstract}

Keywords: Production, Management, Pedal Power, Competitiveness and Welfare.

\section{Introduction}

Based on the geographical location of the Carat village bordering the village of Bulusari (South), the village of Kejapanan (East) of the Porong river (North) and the village of Watukosek (West) and located in a varied topography, the western part tends to be high, because it is in the Watukosek fold line at the ground level flat dominant. Government centered in Carat Hamlet RT. 03 RW. 03, divided into 2 namely Carat sub-village with normal / moderate topography and Raos Baru sub-village with low topography (BPS Pasuruan Regency, 2014).

The large number of residents who work as factory employees with the thought of earning a higher income, resulting in the economic condition of the Carat village depending on the large industrial sector (32\%), small industry $(16 \%)$ and paddy fields and plantations (29\%). From the results of the identification of the PKM team, here are some industries around Carat village:
Received: 01 Agustus 2019. Accepted: 19 Agustus 2019

Table 1. Some Industries around Carat Village

\begin{tabular}{ll}
\hline \multicolumn{1}{c}{ Industrial Name } & \multicolumn{1}{c}{ Production result } \\
\hline 1. PT. Wika Beton & $\begin{array}{l}\text { Concrete piles, Concrete railroad pads, } \\
\text { and others } \\
\text { stink lily (Umbi iles-iles) becomes } \\
\text { konyaku }\end{array}$ \\
2. PT. Ambico & Alas kaki footwear \\
3. PT. Tricopla & Paving block \\
4. PT. Focon & Rumput laut (seaweed) \\
Indonesia & Slipper and Pie Cookies \\
5. PT. Centram & Rice, cucumbers, cantaloupe, roses and \\
6. Industri Kecil & others \\
7. Persawahan dan &
\end{tabular}

However, the development of the industry is not in line with the preservation of environmental quality. This can be seen from the physical changes in the river that are white and smell bad, as an indicator has been polluted. In fact, the ground water is a source of life to irrigate rice fields and gardens in the village of Carat (Umaroh, 2016), as shown in figure 2 below: 

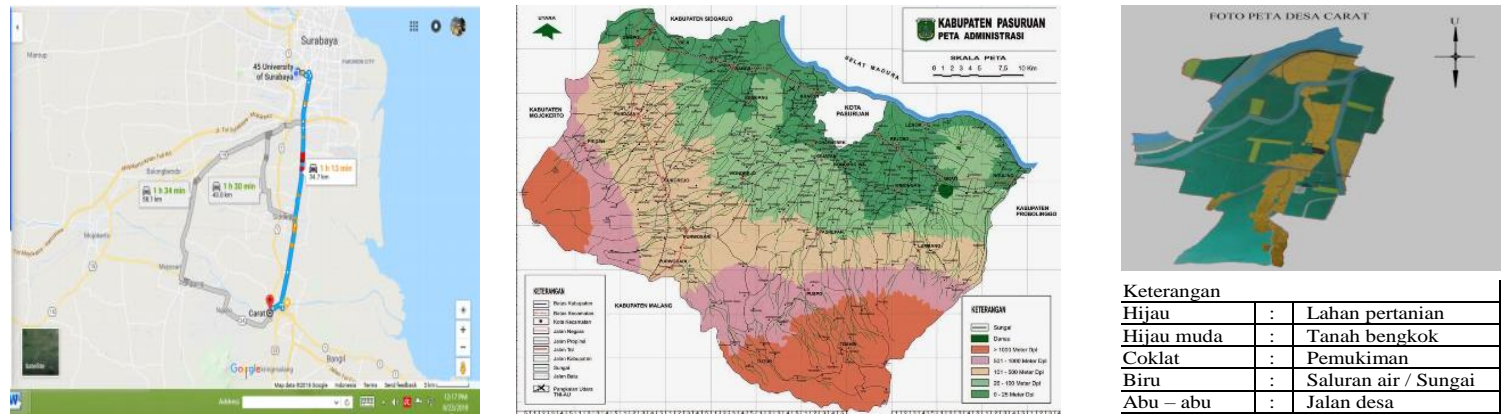

Figure 1. Location Map and Topographic Profile of Carat Village (Hatta., M, 2018)
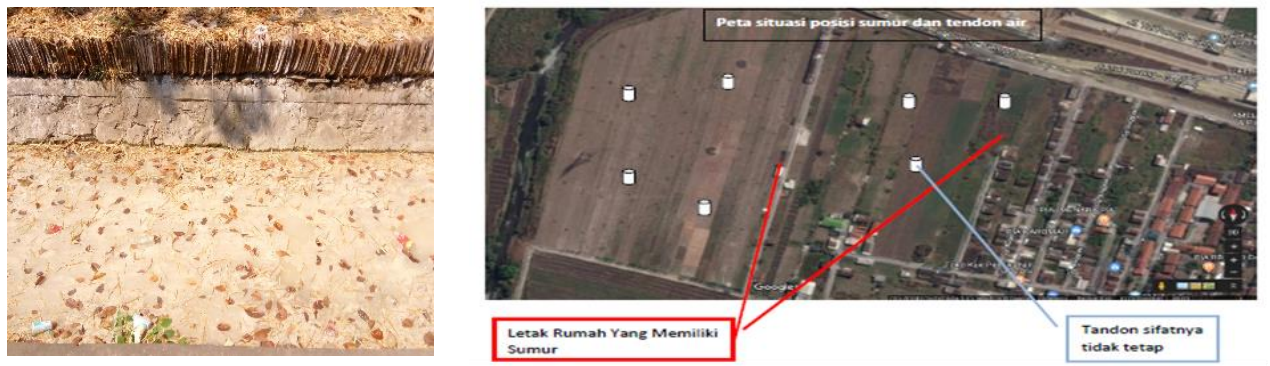

Figure 2. River Conditions and Irrigation Processes in Gardening Activities in Carat Village

The opportunity to develop Carat village, especially in the paddy sector with a land area of 130 hectares and a plantation sector with a land area of 60 hectares, looks quite good. However, it is hampered by arid land conditions due to lack of irrigation which is only done once a week from one 100 litter displacement reservoir in the middle of the plantation. Water from two wells is located quite far from the houses taken by diesel engines for rent at a cost of Rp. 100,000 per person or two workers who are paid Rp. 70,000 per day to irrigate paddy fields within $\pm 100-200$ meters by carrying a paddy weighing $\pm 20 \mathrm{~kg}$ for up to 3 months of harvest.

This is very ineffective and inefficient, and affects the fertility of plants which results in a decrease in crop yields, unfulfilled market needs, so that the situation of farmers is less prosperous and causes young children prefer to become factory workers. This condition is exacerbated by the fact that it does not yet have a dam to collect river water to be channelled to the rice fields and people's gardens. To expedite their agricultural and plantation activities, the residents carry out semi-technical irrigation by opening or closing small river dams and then flowing it into gardens and rice fields that need water. Currently there are several types of irrigation that are commonly used, namely: 1) Surface irrigation; 2) Local Irrigation; 3) Irrigation by spraying; 4) Traditional irrigation with a bucket; 5) Irrigation water pump; and 6) Dry land irrigation (Rai and Mauria (2006); Susana (2014)).

Two hired laborers are tasked with drawing water from wells to be filled into reservoirs and to irrigate rice fields using buckets or rags carried on shoulders or carrying them. Draw water, fill reservoirs and irrigate rice fields are repetitive and excessive activities that are tiring enough to cause injury to the spine, muscle tissue and joints. Any manual activity carried out with unnatural body posters can result in complaints such as aches, tingling, and pain in the bones (Ginting and Malik, 2016). Whereas work done with incorrect work posters, heavy loads and non-ergonomic tools can cause musculoskeletal disorders (Mahardika and Pujotomo, 2014).

Therefore, it is necessary to design a tool with the application of ergonomics because ergonomics is a science that examines limitations, strengths, and human characteristics by utilizing information to design products, machines, facilities, environment, and even work systems in order to achieve the best quality work without ignoring health, safety, and human comfort aspects of its users (Sumardi, 2015). The benefits of implementing ergonomics are reducing work accidents and work-related morbidity, reducing medical costs, compensation and stress, improving productivity and work flow and creating a sense of security because they are free from injury and 
increased job satisfaction (Sulaiman and Sari, 2018).

From the description of the condition of groundwater sources in Carat Village that are still not polluted by factory waste, we innovated a tool to expedite the irrigation system to rice fields and gardens by applying pedal power to save time, energy and energy expended, and increase: crop yields, farmer productivity, and competitiveness compared to farmers' yields outside Carat Village so that the welfare of the population is achieved. According to Hatta (2014) that human power can be transformed through bicycle pedals replacing the power source needed to turn the water pump that can be done at any time even without electricity.

\section{Method}

The implementation method is the description of the stages in applying the solutions that have been offered to overcome the irrigation problem in Carat Village, as follows:

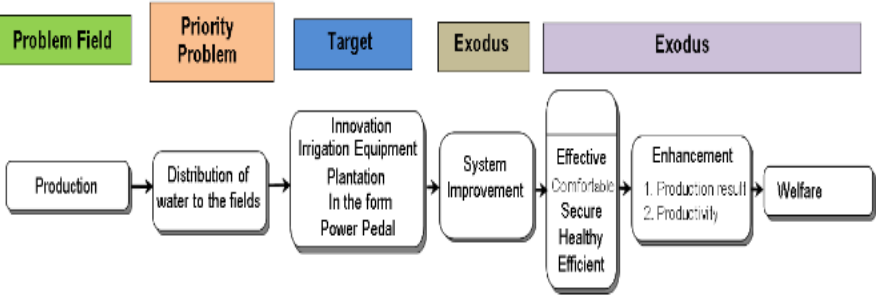

Figure 3. Steps in Implementing Solutions to Partner Problems in Production

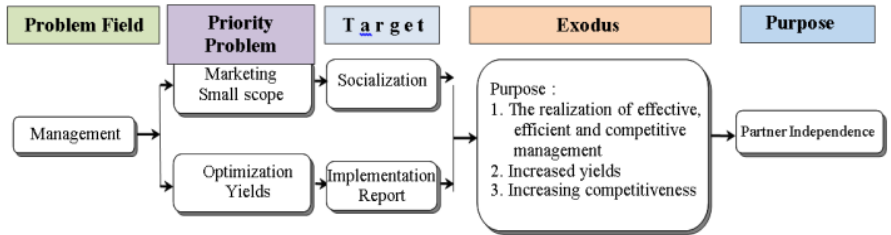

Figure 4. Steps in Implementing Solutions to Partner Problems in the Field of Management

\section{Results and Discussion}

Of all the proposed activities, used to determine the solutions and target outputs to be achieved, with the hope that will affect the increase in productivity, yields and competitiveness to meet market demand, and the realization of an effective, efficient and competitive business,
Table 3. Priority of Problems, Solutions, and Results of Solutions

\begin{tabular}{|c|c|c|}
\hline Problem Priority & The solution & Solution Results \\
\hline $\begin{array}{l}\text { Inefficient and effective process } \\
\text { of taking water from wells using } \\
\text { only manual pulleys to be } \\
\text { distributed to plantation land. }\end{array}$ & \multirow{3}{*}{$\begin{array}{l}\text { Design pedal power that has concepts } \\
\text { such as pedaling a bicycle, so that the } \\
\text { creation of effectiveness and } \\
\text { efficiency in irrigation of plantation } \\
\text { land. As a result of the change in } \\
\text { kinetic energy from the pedal power, } \\
\text { water will flow through the hoses } \\
\text { stretched to the plantation land. So } \\
\text { that farmers can directly water the } \\
\text { plants evenly with a hose. }\end{array}$} & \multirow[t]{3}{*}{$\begin{array}{l}\text { Power pedal that can } \\
\text { save energy. }\end{array}$} \\
\hline $\begin{array}{l}\text { The distance between the water } \\
\text { source and the plantation land is } \\
\text { too far. }\end{array}$ & & \\
\hline $\begin{array}{l}\text { Irrigation of plantation land can } \\
\text { only use a fan or a } 5 \text { liter bucket. }\end{array}$ & & \\
\hline $\begin{array}{l}\text { Crop marketing is still within } \\
\text { the scope of Carat village. }\end{array}$ & $\begin{array}{l}\text { Marketing with direct socialization to } \\
\text { find out market demand. }\end{array}$ & $\begin{array}{l}\text { Establish cooperation } \\
\text { and good relations } \\
\text { with } \quad \text { market } \\
\text { participants. }\end{array}$ \\
\hline $\begin{array}{l}\text { Not yet optimal monitoring of } \\
\text { crop yields in each period. }\end{array}$ & $\begin{array}{l}\text { Implementation of yield reports in } \\
\text { each period. }\end{array}$ & $\begin{array}{l}\text { Report on yields for } \\
\text { each period. }\end{array}$ \\
\hline $\begin{array}{l}\text { Farmers cannot determine the } \\
\text { selling price in each harvest } \\
\text { season because of the capital } \\
\text { dependence of the middlemen to } \\
\text { prepare for the next planting } \\
\text { period. }\end{array}$ & $\begin{array}{l}\text { Form farmer groups and collaborate } \\
\text { with local governments or } \\
\text { cooperatives }\end{array}$ & $\begin{array}{l}\text { The formation of } \\
\text { independent and } \\
\text { prosperous farmer } \\
\text { groups }\end{array}$ \\
\hline
\end{tabular}

\section{- PKM Program Activities}

\section{Location of Activities or Partner Activities}

The activities or activities of partners so far have been carried out in Carat Village, Gempol District, Pasuruan Regency, and East Java Province.

\section{Condition of Plantation Land and Harvest Products}

The estate located next to Pak Lahuk's house looks very barren and barren due to lack of irrigation. But thanks to his persistence so far, the land can still provide sufficient yields for the needs of his family's life so far.
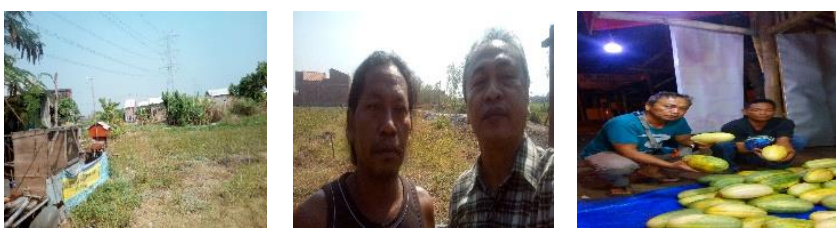

Figure 5. Land Condition, Me and Mr Lahuk, and Harvest Results (Hatta, M., et al, 2018)

3. Description of Science and Technology to Be Implemented at Partners

The following is a description of science and technology that will be implemented on partners; 1) The field of production with the innovation of irrigation equipment that applies the Ergonomic principles, and 2). In the field of management with training and mentoring on several matters related to business management and increasing crop yields and farmer productivity in order to realize prosperity and independence, as described in Figure 6. 


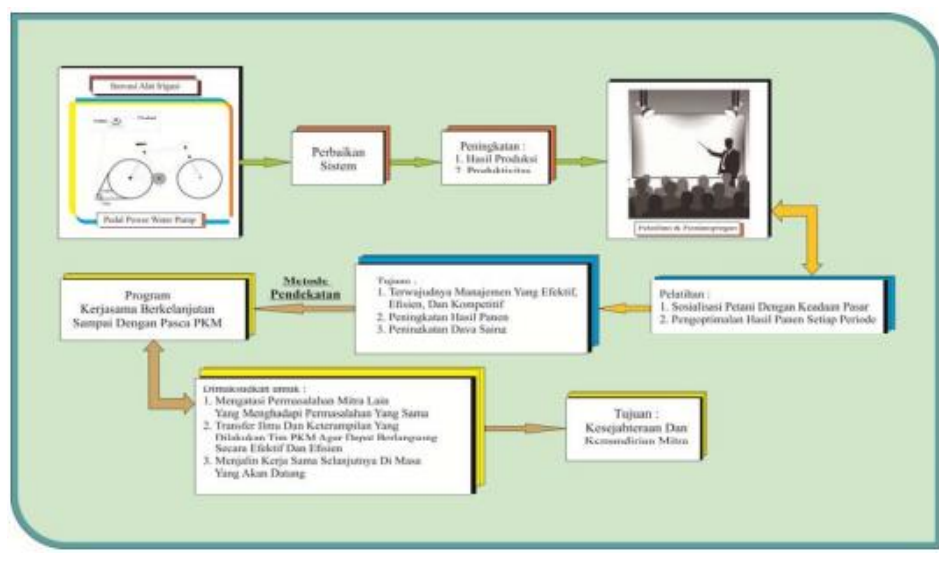

Figure 6. Overview of Science and Technology to Be Implemented in Partners (Hatta, M., et al, 2018)

\section{Conclusion}

Some conclusions that the author can convey are:

1. The problem in the field of production was solved by innovating an irrigation device to drain water into the fields and gardens named pedal power, aiming to save time and energy to increase yields, productivity and competitiveness of Carat village farmers.

2. For the solution of the problems in the field of management is to provide training and assistance related to business management and increase farmer productivity in order to achieve the welfare of the surrounding community and the independence of partners.

3. The two solutions above will be implemented by the PKM Grant Team during the Training and Mentoring event with a theme "Application of Pedal Powered Water Pumps for Plantation Irrigation in Carat Village, Gempol District, Pasuruan Regency, East Java Province", planned around May 2019.

4. The publication of the event was carried out on YouTube and Surya Daily (Newspaper and Tribunnews online media) as one of the outcomes that the PKM Grant Team had promised when submitting the proposal.

\section{References}

Statistik, B. P. (2014). Kecamatan Gempol Dalam Angka 2014. BPS Kabupaten Pasuruan.

Umaroh.( 2016). Tipologi Desa Carat Kecamatan Gempol Kabupaten Pasuruan. (https://umaroh31.wordpress.com/2016/12/0 5/tipologi-desa-caratkecamatangempolkabupaten-pasuruan/) diakses pada tanggal 5 Agustus 2018.
Rai, M. and Mauria, S. (2006). Handbook of Agriculture. Indian Council of Agricultural Research. New Delhi.

Susana, W. (2014). Optimalisasi Pola Tanam Padi Sawah Di Daerah Irigasi Way Ketibung Kabupaten Lampung Selatan (Tesis, Universitas Lampung).

Ginting, R., \& Malik, A. F. (2016). Analisis Keluhan Rasa Sakit Yang Dialami Pekerja Pada Ukm Sepatu Kulit Di Kota Dengan Menggunakan Kuesioner $S N Q$. Jurnal Sistem Teknik Industri, 18(1), 1519.

Mahardika, T., \& Pujotomo, D. (2014). Perancangan Fasitilas Kerja Untuk Mengurangi Keluhan Musculoskeletal Disorders (Msds) Dengan Metode Rappid Entire Body Assesment Pada Pekerja Pembuatan Paving Dan Batako Pada UKM USAha Baru. J@ ti Undip: Jurnal Teknik Industri, 9(2), 109-116.

Sumardi, A. (2015). Perbaikan Sistem Kerja Dengan Pendekatan Ergonomi Total Guna Peningkatan Kenyamanan Pekerja (Studi Kasus di UKM Genteng Press SK 2, Godean KM 11, Sleman). Tesis, UPN" Veteran" Yogyakarta.

Sulaiman, F., \& Sari, Y. P. (2018). Analisis Postur Kerja Pekerja Proses Pengesahan Batu Akik dengan Menggunakan Metode Reba. Jurnal Teknovasi: Jurnal Teknik dan Inovasi, 3(1), 16-25.

Hatta, M. (2014). Rancangan Pompa Air Bertenaga Pedal. Jurnal Teknik Industri, 13(21).

Hatta, M., Tjahjani., I.K., dan Wicaksono, A.S. (2018). PKM Efisiensi Biaya Produksi Pada Petani Buah Dengan Pemanfaatan Tenaga Sepeda di Desa Carat Kecamatan Gempol Kabupaten Pasuruan Provinsi Jawa Timur. Usulan Program Kemitraan Masyarakat. Universitas 45 Surabaya. 